\title{
The Utilization of Carbon Electrodes to Reduce Dissolved Ions from Coal Stockpile Wastewater
}

\author{
Andi Arif Setiawan ${ }^{1 *}$, Reno Fitriyant ${ }^{\mathrm{i} 2}$ \\ ${ }^{1}$ Lecturer at the Faculty of Science and Technology, University of PGRI Palembang, Indonesia \\ ${ }^{2}$ Lecturer at the Faculty of Engineering, University of PGRI Palembang, Indonesia \\ *Corresponding Author aaschem90@gmail.com
}

Article history

\begin{tabular}{llll} 
Received & Received in revised form & Accepted & Available online \\
4 May 2021 & 12 January 2022 & 31 January 2022 & 31 January 2022 \\
\hline
\end{tabular}

\begin{abstract}
The advancement of science and technology plays an important role in encouraging industrial progress. Industrial progress has a positive impact on the economy. On the other hand, it has a negative impact in the form of pollution. The industrial activities include the coal mining industry. The electrolysis provides an effective way to reduce the pollutant from the wastewater through an electrochemical reaction between the cathode and anode. The purpose of this study was to examine the length of electrolysis and the amount of electric current used to reduce dissolved ions and total dissolved solids from coal stockpile wastewater. The method had used the survey of coal stockpile location and wastewater sampling, then followed by waste treatment using electrolysis. The results show the increase in electrolysis time has a positive relationship decreasing dissolved ions in the coal stockpile wastewater. The combination between 120 minutes electrolysis time and $3 \mathrm{~A}$ electric current showed the highest decrease in dissolved ions by an average of $1,692.3 \mu \mathrm{s} / \mathrm{cm}$ from the beginning before treatment of $1772 \mu \mathrm{s} / \mathrm{cm}$. The highest decrease in total dissolved solids was $660.67 \mathrm{ppm}$ from the beginning before treatment of $909 \mathrm{ppm}$. This decrease had occurred because the longer electrolysis time and electric current are used greater, the more dissolved ions will be electrolyzed is in line with Faraday's law.
\end{abstract}

Keywords: electrolysis, coal stockpile wastewater, length of time, current strength

\section{Introduction}

The development of science and technology has a double impact, on the one hand it has a positive impact on the industry in improving the economy, but on the other hand it has a negative impact on the environment in the form of pollution. One of the industrial that has the potential to pollute the environment is coal stockpile[1].

Industrial activities and coal mining have a major contribution to environmental pollution [2], [3]. These pollutants include heavy metals [4] dissolved in the form of ions, which are generated from mining activities [5], so they can pollute the environment. Heavy metals are natural components of rock in the earth, which have been known for hundreds of years to be toxic and harmful to human health [6]. The entry of chemical elements into the environment due to natural processes and human activities results an increasing of these pollutants in surface water, sedimen, and soil [7]. Pollution in surface water has a strong effect on water and soil pollution. Pollutants exposure through water will enter the soil [8], which comes from mining activities that threatening human health. These pollutants enter the human body through the mouth and also respiration and skin contact.

Pollution in these waters is influenced by the solubility of the elements contained in these mining materials, one of those is coal mining. The solubility of heavy metals in coal is faster as the higher sulfur content in coal. The high sulfur content in these mining materials has an impact on the acidity of the mine area [9]. This condition causes more heavy metals to be dissolved and carried away by the flow of water, causing pollution of water and soil [10]. This pollution impacts aquatic ecosystems [11], agricultural land [12], [13] and ultimately disrupts food security.

In the phenomenon of dissolved ion-ion pollution, it is necessary to find a solution to reduce the impact on organisms. An alternative to dealing with this pollution is by electrolysis [14], [15], [16]. This electrolysis event is influenced by the type of electrode [17], [16], electrode distance, electric voltage [14], the length of time for electrolysis, and the $\mathrm{pH}$ of the solution [18]. Electrolysis is an event of utilize electrical energy through the media (electrodes) that the pollutant ions in the water will go to the positive and negative electrodes. The positively charged metal ions will go to the negative electrode (Cathode), while the negative ions will go to the positive electrode (Anode). These electrodes can be made of metal, but metal electrodes have weaknesses. The weakness of an electrode made of metal is the anode electrode (positive) will be oxidized that could contaminate besides the relatively expensive metal price. An alternative to solve this problem is by utilizing carbon electrodes from used batteries.

The purpose of this study was to analyze the 
decrease in dissolved ions and dissolved solids from coal stockpile waste due to variations in the length of time of electrolysis and variations in electric current.

\section{Material and Methods}

\section{1. Materials}

The materials used: sample of wastewater from Keramasan Kertapati coal stockpile Palembang City Indonesian, alcohol, distilled water, filter paper and, sandpaper. The tools used are electrodes; digital balance; volume pipette; beaker glass; transformers: 1 , 3 , and 5 amps; leveling diode; cable, clamp, multi tester; Total Dissolved Solids (TDS) meter, Electrical Conductivity (EC) meter, balance and sample bottles.

\subsection{Methods}

Water samples were taken at the Keramasan Kertapati coal stockpile waste reservoir in Palembang. The sample is first cleaned of impurities such as twigs and plastic, then taken and put into a dark bottle.

\subsection{Experimental}

Preparation of the power supply (figure 1) and carbon electrodes from used batteries.

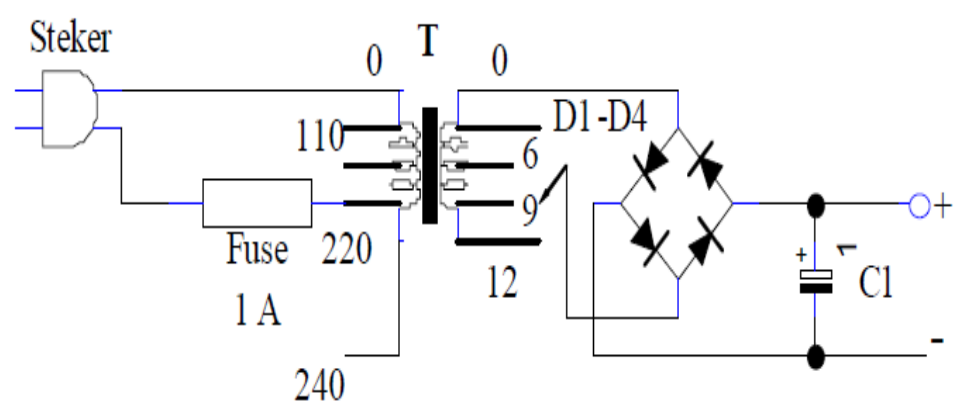

Figure 1. Power supply circuit for electrolysis

The power supply (figure 1) is connected to the electrolysis system(figure 2). Electrolysis was carried out by varying the length of time for electrolysis of 30 , 60,90 , and 120 minutes with an electric current of 1 $\mathrm{A}, 3 \mathrm{~A}$, and $5 \mathrm{~A}$.

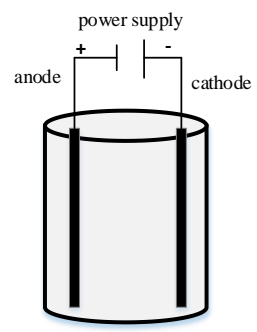

Figure 2. Electrolysis Process

Measurement of the reduction of dissolved ions from coal stockpile waste using EC meters and the decrease in total dissolved solids using a TDS meter.

\subsection{Data Analysis}

The data obtained are analyzed for each treatment, the duration of electrolysis, and the amount of electric current on the decrease in dissolved ions and the decrease in total dissolved solids. Statistical analysis using 2-factor analysis of variance (type of electrode and electric current) using the SPSS program, if $\mathrm{F}$ count $>\mathrm{F}$ Table $5 \%$ means each treatment shows a significant effect on the reduction of heavy metal content. Data analysis was followed by an analysis of the Least Significant Difference (LSD).

\section{Results and Discussion}

\subsection{Decreasing in Dissolved Ions in Stockpile Wastewater}

The results of various treatments of electrolysis time from 30 minutes to 120 minutes with 30 minutes intervals and variations of electric current of 1,2 , and $3 \mathrm{~A}$ on the reduction of dissolved ions from the coal stockpile waste, obtained a graph of the reduction of dissolved ions (Figure 3). 


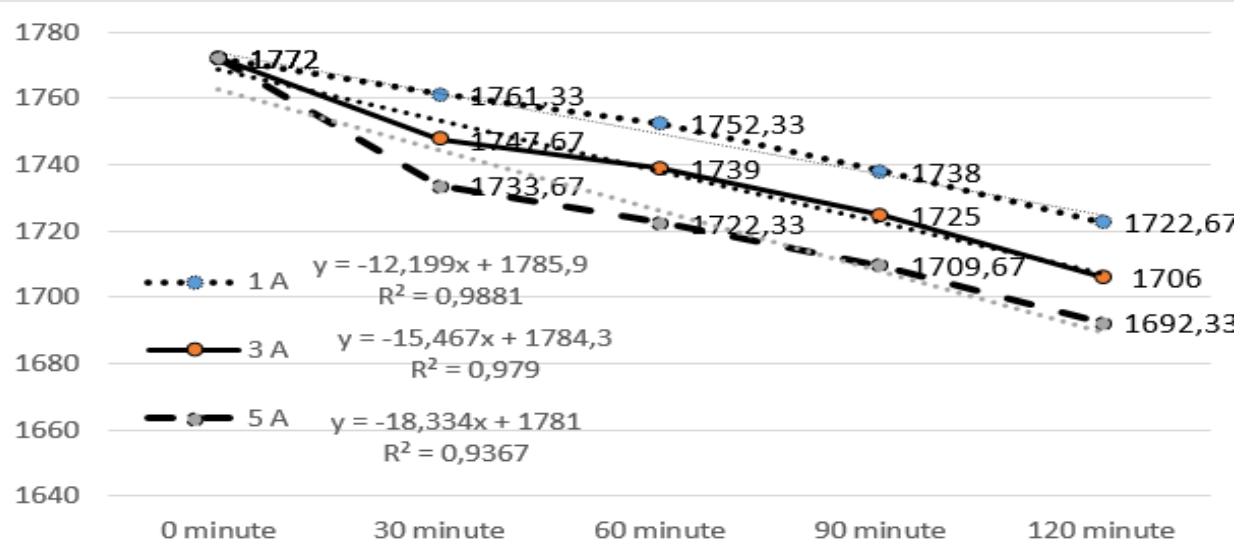

Figure 3 Decreasing in Dissolved Ions Content in Wastewater Coal Stockpile from Electrolysis Process

Figure 3 shows that the longer electrolysis and the greater electric current are used, has results decreasing in dissolved ions from coal stockpile waste. This is in accordance with Faraday's $1^{\text {st }}$ law, that the amount of electrolysis is influenced by the length of time of electrolysis and the amount of electric current used [19].

The positively charged ions will move towards the negatively charged electrode (cathode), as well as the negatively charged ions will move towards the positively charged electrode (anode). The electrolysis mechanism of dissolved ions is depicted in Figure 4.

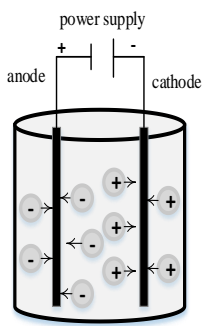

Figure 4. Electrolysis Mechanism

Textile dyes can be decomposed using the electrolysis method that the longer e electrolysis time [18] which the more dye decomposed [20]. In line with the research conducted by Curteanu, the longer electrolysis time causes a decrease in TSS, COD, and chlorophyll content in wastewater [21]. Research conducted by Kapalka revealed that the amount of electric current used has an effect on the reduction of organic pollutants in waste water. [22] Figure 3 also shows that there is a very strong relationship between the length of time of electrolysis $t$ on the decrease in dissolved ions which the correlation coefficient value is above $(\mathrm{R} 2)>0.9$.

The equation model for the reduction of dissolved ions for electric currents $1 \mathrm{~A}, 3 \mathrm{~A}$ and $5 \mathrm{~A}$, respectively $\mathrm{y}=-12.193 \mathrm{x}+1,785.8 ; \mathrm{y}=-15.47 \mathrm{x}+$ 1784.4 and $y=-18.34 x+1,781$. The reduction of the dissolved ions in Figure 3 also shows negative slope value (slope) which means each treatment is the length of time electrolysis, and the amount of electric current shows a decrease (the downward direction of the graph). The equation also shows that when the electrolysis time increases by 1 minute, the dissolved ion values for $1 \mathrm{~A}, 3 \mathrm{~A}$ and $5 \mathrm{~A}$ are $1,797.993 \mu \mathrm{s} / \mathrm{cm}$ respectively; $1,768.30 \mu \mathrm{s} / \mathrm{cm}$ and $1,765.660 \mu \mathrm{s} / \mathrm{cm}$. The results of the analysis of 2 factor electric current factor and electrolysis time using the SPSS program obtained the data from Table 1.

Table 1. Analysis of Variety of 2 factor Electric Current Factors and Electrolysis Time on EC

Dependent Variable: EC

\begin{tabular}{lrrrrr}
\hline Source & \multicolumn{1}{c}{ Type III Sum of Squares } & df & Mean Square & F & Sig. \\
\hline Corrected & $13754.667^{\mathrm{a}}$ & 11 & 1250.424 & 121.335 & .000 \\
Model & 107661376.000 & 1 & 107661376.000 & 10446925.97 & 3 \\
Intercept & 8478.000 & 3 & 2826.000 & 274.221 & .000 \\
& 5251.167 & 254.774 & .000 \\
minute & 25.500 & 2583 & .000 \\
amper & 247.333 & 6.250 & .412 & .863 \\
minute & 107675378.000 & 24 & 10.306 & \\
amper & 14002.000 & 36 & & & \\
Error & & 35 & & & \\
Total & & & & & \\
Corrected & & & & & \\
Total & & & & & \\
\hline
\end{tabular}

a. R Squared $=.982$ (Adjusted R Squared $=.974)$ 
Table 1 shows that the electric current and the length of time of electrolysis show a significant effect on the reduction of dissolved ions with calculated $\mathrm{F}$ values of 274.221 and 275.0922 .603 , respectively, by a sign value (Sig.) $0.00<0.05(5 \%)$. Meanwhile, the reaction between electric current and electrolysis time did not show a significant effect on the reduction of dissolved ions in the stockpile waste. It is indicated by the calculated $F$ value of 0.142 and the sign value (sig.) of $0.863>5 \%$. The results of further analysis to see the level of difference in each treatment carried out the LSD analysis, obtained Table 2.

Table 2. Analysis of LSD between Electrolysis Time Treatment to Decrease Dissolved ions from Coal Stockpile Water Waste

\begin{tabular}{|c|c|c|c|c|c|c|}
\hline $\begin{array}{l}\text { Depende } \\
\text { LSD }\end{array}$ & Jariable: & EC & Compa & sons & & \\
\hline \multirow[b]{2}{*}{$\begin{array}{l}\text { (I) } \\
\text { minute }\end{array}$} & \multirow[b]{2}{*}{$\begin{array}{l}(\mathrm{J}) \\
\text { minute }\end{array}$} & \multirow{2}{*}{$\begin{array}{c}\text { Mean } \\
\text { Difference } \\
\text { (I-J) }\end{array}$} & \multirow[b]{2}{*}{$\begin{array}{l}\text { Std. } \\
\text { Error }\end{array}$} & \multirow[b]{2}{*}{ Sig. } & \multicolumn{2}{|c|}{$\begin{array}{l}\text { 95\% Confidence } \\
\text { Interval }\end{array}$} \\
\hline & & & & & $\begin{array}{l}\text { Lower } \\
\text { Bound }\end{array}$ & $\begin{array}{l}\text { Upper } \\
\text { Bound }\end{array}$ \\
\hline \multirow[t]{3}{*}{1} & 2 & $9.00^{*}$ & 1.513 & .000 & 5.88 & 12.12 \\
\hline & 3 & $23.33^{*}$ & 1.513 & .000 & 20.21 & 26.46 \\
\hline & 4 & $40.56^{*}$ & 1.513 & .000 & 37.43 & 43.68 \\
\hline \multirow[t]{3}{*}{2} & 1 & $-9.00^{*}$ & 1.513 & .000 & -12.12 & -5.88 \\
\hline & 3 & $14.33^{*}$ & 1.513 & .000 & 11.21 & 17.46 \\
\hline & 4 & $31.56^{*}$ & 1.513 & .000 & 28.43 & 34.68 \\
\hline \multirow[t]{3}{*}{3} & 1 & $-23.33^{*}$ & 1.513 & .000 & -26.46 & -20.21 \\
\hline & 2 & $-14.33^{*}$ & 1.513 & .000 & -17.46 & -11.21 \\
\hline & 4 & $17.22^{*}$ & 1.513 & .000 & 14.10 & 20.35 \\
\hline \multirow[t]{3}{*}{4} & 1 & $-40.56^{*}$ & 1.513 & .000 & -43.68 & -37.43 \\
\hline & 2 & $-31.56^{*}$ & 1.513 & .000 & -34.68 & -28.43 \\
\hline & 3 & $-17.22^{*}$ & 1.513 & 000 & -20.35 & -14.10 \\
\hline
\end{tabular}

Table 2 shows that the length of time electrolysis treatment shows a significant difference (significant) at the $0.05(5 \%)$ level, this is marked with a $*$ sign. The results of the LSD analysis for the differences between the treatment of electric currents are obtained in Table 3.

Table 3. Analysis of LSD between Electric Flow Against the EC value of Coal Stockpile Water Waste

\begin{tabular}{|c|c|c|c|c|c|c|}
\hline $\begin{array}{l}\text { Depende } \\
\text { LSD }\end{array}$ & t Variab & EC & Comp & isons & & \\
\hline \multirow[b]{2}{*}{$\begin{array}{l}\text { (I) } \\
\text { amper }\end{array}$} & \multirow[b]{2}{*}{$\begin{array}{l}\text { (J) } \\
\text { amper }\end{array}$} & \multirow{2}{*}{$\begin{array}{c}\text { Mean } \\
\text { Difference } \\
\text { (I-J) }\end{array}$} & \multirow[b]{2}{*}{$\begin{array}{l}\text { Std. } \\
\text { Error }\end{array}$} & \multirow[b]{2}{*}{ Sig. } & \multicolumn{2}{|c|}{$\begin{array}{l}\text { 95\% Confidence } \\
\text { Interval }\end{array}$} \\
\hline & & & & & $\begin{array}{l}\text { Lower } \\
\text { Bound }\end{array}$ & $\begin{array}{l}\text { Upper } \\
\text { Bound }\end{array}$ \\
\hline 1 & 2 & $14.67^{*}$ & 1.311 & .000 & 11.96 & 17.37 \\
\hline & 3 & $29.58^{*}$ & 1.311 & .000 & 26.88 & 32.29 \\
\hline 2 & 1 & $-14.67^{*}$ & 1.311 & .000 & -17.37 & -11.96 \\
\hline & 3 & $14.92^{*}$ & 1.311 & .000 & 12.21 & 17.62 \\
\hline 3 & 1 & $-29.58^{*}$ & 1.311 & .000 & -32.29 & -26.88 \\
\hline & 2 & $-14.92^{*}$ & 1.311 & .000 & -17.62 & -12.21 \\
\hline
\end{tabular}

*. The mean difference is significant at the 0.05 level.

Table 3 shows that the difference in treatment between electric currents shows a significant difference in the reduction of dissolved ions. This is marked with an *

\subsection{Decreasing Dissolved solids in Stockpile wastewater}

The results of the treatment of the length of electrolysis and the amount of electric current used to reduce the TDS are shown in Figure 5.

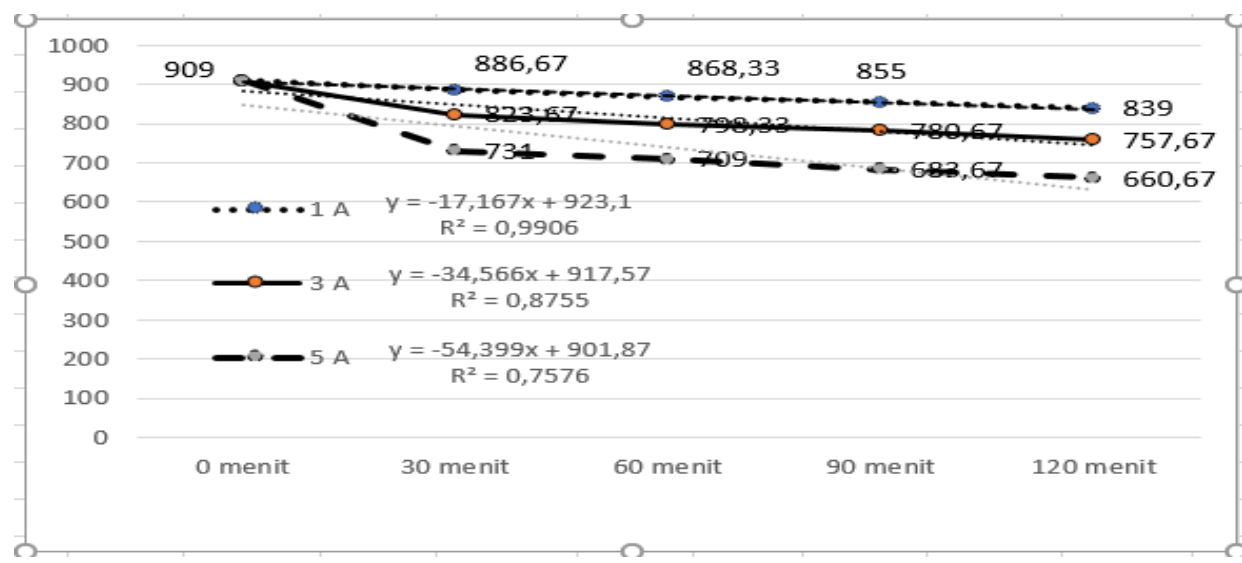

Figure 5 Decreasing in TDS (ppm) in Wastewater Coal Stockpile

Figure 5 shows that decreasing of Total Dissolved Solids (TDS) in coal stockpile wastewater shows a decrease with the longer electrolysis time and the greater electric current used. This is due to the longer contact between the electrode which is electrified with the waste, resulting in more dissolved solids that will undergo electrolysis, as well as the higher the electric current used, the higher the dissolved solids in the coal stockpile waste will decrease. This is in line with research conducted by Curteanu stated that the greater electric current used in the waste electrolysis process, the greater decrease in Total Solid Suspended (TSS) in wastewater [21]. The results of research that has been carried out by Priya and Palanivelu in term of the reduction the TDS parameter from textile industry waste can be done using the electrodialysis method that the method of using an electric current through the cathode and anode electrodes separated by a membrane [23].

Figure 5 shows the pattern of decreasing TDS is in the form of a straight line, so from this pattern it can be expressed in the linear regression equation of the 
reduction in TDS in coal stockpile wastewater shown for electric currents $1 \mathrm{~A}, 3 \mathrm{~A}$ and $5 \mathrm{~A}$ respectively $\mathrm{y}=$ $-17.167 x+923.1 ; y=-34.566 x+917.57$ and $y=-$ $54.399 \mathrm{x}+901.87$. This means that the equation model was shown at currents of $1 \mathrm{~A}, 3 \mathrm{~A}$ and $5 \mathrm{~A}$ when the time increases by 1 unit, the TDS value in the waste sample is 905.933 respectively; 882,403 and 843.47 $\mathrm{ppm}$. This proves that an increase in electric current indicates a decrease in the TDS value in the coal stockpile wastewater sample.

Figure 5 also shows the correlation coefficient between the length of time electrolysis with an electric current of $1 \mathrm{~A}, 3 \mathrm{~A}$, and $5 \mathrm{~A}$ on the decrease in the TDS value of the wastewater samples obtained $R^{2}=0.9906$; $\mathrm{R}^{2}=0.8755$ and $\mathrm{R}^{2}=0.7576$ respectively. This shows that the length of time and the increase in electric current show decrease in the TDS value of the wastewater sample. This is in line with Faraday's $1^{\text {st }}$ law that the amount of substance is electrolyzed as directly of current used [19][24].

The TDS parameter is one of the important solids in water, containing various minerals [25]. The mechanism to decrease the TDS content is the electrolysis process in coal stockpile wastewater samples, that the minerals in the wastewater undergo electrolysis they will be ionized. Negative ions to the cathode and positive ions to the anode (Fig. 3).

Shim conducted a study on wastewater from ground washing using electrolysis. The result showed the electrolysis method is able to overcome heavy metals and particles in the wastewater [26]. Kim argues from the results of his research that the use of electrolysis method is able to overcome organic material pollution that comes from agricultural industrial waste [15]. The results of the 2-factor variance analysis using the SPSS program obtained data in Table 4

Table 4. Analysis of Variety of 2 factor Electric Current Factors and Electrolysis Time on TDS

Tests of Between-Subjects Effects

\begin{tabular}{lrrrrr}
\multicolumn{2}{l}{ Dependent Variable: EC } & & & & \\
\hline Source & $\begin{array}{c}\text { Type III Sum } \\
\text { of Squares }\end{array}$ & df & Mean Square & \multicolumn{1}{c}{ F } & Sig. \\
\hline Corrected & $12331.889^{\mathrm{a}}$ & 11 & 1121.081 & 115.642 & .000 \\
Model & 107820533.4 & & 107820533.4 & 11121888.83 & \\
Intercept & 44 & 1 & 44 & 7 & .000 \\
& 6846.778 & 3 & 2282.259 & 235.419 & .000 \\
current & 5333.722 & 2 & 2666.861 & 275.092 & .000 \\
time & 151.389 & 6 & 25.231 & 2.603 & .044 \\
current * time & 232.667 & 24 & 9.694 & & \\
Error & 107833098.0 & 36 & & & \\
Total & 00 & & & & \\
Corrected & 12564.556 & 35 & & & \\
Total & &
\end{tabular}

a. R Squared $=.981$ (Adjusted R Squared $=.973)$

Table 4 shows that time, electric current, and the interaction of time and current on the decrease in TDS content show a significant effect. It is indicated by the large calculated $\mathrm{F}$ values with sign values (sig.) 0.044
$<5 \%(0.05)$ of each $104.274 ; 3227,870$ and 117.608 respectively. The results of the LSD further test to see the level of difference in each treatment (time and electric current) using the SPSS program has obtained data from Tables 5 and 6.

Table 5. Analysis of the LSD between Electrolysis Time and the TDS value of Coal Stockpile Water Waste

Dependent Variable: TDS

$$
\text { Multiple Comparisons }
$$

\begin{tabular}{|c|c|c|c|c|c|c|}
\hline \multirow{3}{*}{$\begin{array}{l}\text { (I) } \\
\text { time }\end{array}$} & \multicolumn{3}{|c|}{ Mean } & & \multicolumn{2}{|c|}{ 95\% Confidence Interval } \\
\hline & (J) & Difference & Std. & & Lower & \\
\hline & timeu & $(\mathrm{I}-\mathrm{J})$ & Error & Sig. & Bound & Upper Bound \\
\hline \multirow[t]{3}{*}{1} & 2 & $21.89^{*}$ & 1.631 & .000 & 18.52 & 25.26 \\
\hline & 3 & $40.67^{*}$ & 1.631 & .000 & 37.30 & 44.03 \\
\hline & 4 & $61.33^{*}-x-\ln$ & 1.631 & .000 & 57.97 & 64.70 \\
\hline \multirow[t]{3}{*}{2} & 1 & $-21.89^{*}$ & 1.631 & .000 & -25.26 & -18.52 \\
\hline & 3 & $18.78^{*}$ & 1.631 & .000 & 15.41 & 22.14 \\
\hline & 4 & $39.44^{*}$ & 1.631 & .000 & 36.08 & 42.81 \\
\hline \multirow[t]{3}{*}{3} & 1 & $-40.67^{*}$ & 1.631 & .000 & -44.03 & -37.30 \\
\hline & 2 & $-18.78^{*}$ & 1.631 & .000 & -22.14 & -15.41 \\
\hline & 4 & $20.67^{*}$ & 1.631 & .000 & 17.30 & 24.03 \\
\hline \multirow[t]{3}{*}{4} & 1 & $-61.33^{*}$ & 1.631 & .000 & -64.70 & -57.97 \\
\hline & 2 & $-39.44^{*}$ & 1.631 & .000 & -42.81 & -36.08 \\
\hline & 3 & $-20.67^{*}$ & 1.631 & .000 & -24.03 & -17.30 \\
\hline
\end{tabular}

Table 6 Analysis of the LSD between Electric Flow and TDS Value from Coal Stockpile Water Waste

\begin{tabular}{|c|c|c|c|c|c|c|}
\hline $\begin{array}{l}\text { Depender } \\
\text { LSD }\end{array}$ & Variable: & Mult & le Com & arison & & \\
\hline \multirow{3}{*}{$\begin{array}{l}\text { (I) } \\
\text { current }\end{array}$} & \multirow{3}{*}{$\begin{array}{l}\text { (J) } \\
\text { Current }\end{array}$} & \multirow{3}{*}{$\begin{array}{c}\text { Mean } \\
\text { Difference } \\
(\mathrm{I}-\mathrm{J})\end{array}$} & \multirow{3}{*}{$\begin{array}{l}\text { Std. } \\
\text { Error }\end{array}$} & \multirow[b]{3}{*}{ Sig. } & \multicolumn{2}{|c|}{$95 \%$ Confidence Interval } \\
\hline & & & & & Lower & \\
\hline & & & & & Bound & Upper Bound \\
\hline 1 & 2 & $72.17^{*}$ & 1.413 & .000 & 69.25 & 75.08 \\
\hline & 3 & $166.17^{*}$ & 1.413 & .000 & 163.25 & 169.08 \\
\hline 2 & 1 & $-72.17^{*}$ & 1.413 & .000 & -75.08 & -69.25 \\
\hline & 3 & $94.00^{*}$ & 1.413 & .000 & 91.08 & 96.92 \\
\hline 3 & 1 & $-166.17^{*}$ & 1.413 & .000 & -169.08 & -163.25 \\
\hline & 2 & $-94.00^{*}$ & 1.413 & .000 & -96.92 & -91.08 \\
\hline
\end{tabular}

Tables 5 and 6 show between treatments, the duration of electrolysis and electric current has a significant difference. This is indicated by an $*$ and a sig. $0.000<5 \%(0.05)$.

\section{Conclusion}

The length of time of electrolysis and the magnitude of the electric current showed a decrease in dissolved ions and TDS. The largest decrease was at 120 minutes with an electric current of 3 ampere, for dissolved ions parameter of $1692.33 \mu \mathrm{s} / \mathrm{cm}$ from the initial value of $1772 \mu \mathrm{s} / \mathrm{cm}$, while the TDS parameter was $660.67 \mathrm{ppm}$ from the initial value of $909 \mathrm{ppm}$.

\section{Acknowledgement}

The author acknowledge the Chancellor of University of PGRI Palembang who funded this research and colleagues and students who assisted in this research. 


\section{References}

[1] A. A. Setiawan, D. Budianta, Suheryanto, and D. P. Priadi, "Review: Pollution due to Coal Mining Activity and its Impact on Environment," Sriwij. J. Environ., vol. 3, no. November 2017, pp. 1-5, 2018, doi: 10.22135/sje.2018.3.1.1-5.

[2] R. K. Tiwary, "Environmental impact of coal mining on water regime and its management," Water, Air, Soil Pollut. 132, vol. 132, pp. 185199, 2001.

[3] D. Mamurekli, "Environmental impacts of coal mining and coal utilization in the UK," Acta Montan. Slovaca Ročník, vol. 15, pp. 134-144, 2010.

[4] T. Fonkou et al., "Heavy metal concentrations in some biotic and abiotic components of the Olezoa wetland complex (Yaoundé-Cameroon, West Africa)," Water Qual. Res. J. Canada, vol. 40, no. 4, pp. 457-461, 2005.

[5] W. Gwenzi and N. M. Mupatsi, "Evaluation of heavy metal leaching from coal ash-versus conventional concrete monoliths and debris," Waste Manag., 2016, doi: 10.1016/j.wasman.2015.12.029.

[6] J. Neustadt and S. Pieczenik, "Heavy-Metal Toxicity-With Emphasis on Mercury," Integr. Med., vol. 6, no. 2, pp. 26-32, 2007.

[7] R. a. Wuana and F. E. Okieimen, "Heavy Metals in Contaminated Soils: A Review of Sources, Chemistry, Risks and Best Available Strategies for Remediation," ISRN Ecol., vol. 2011, pp. 1-20, 2011, doi: 10.5402/2011/402647.

[8] I. P. Online, A. Tmava, S. Avdullahi, and I. Fejza, "Assessment of heavy metal study on groundwater in the mining area in Stan Terg, Kosovo," vol. 3, no. 2, pp. 53-60, 2013.

[9] J. Søndergaard, B. Elberling, and G. Asmund, "Metal speciation and bioavailability in acid mine drainage from a high Arctic coal mine waste rock pile: Temporal variations assessed through high-resolution water sampling , geochemical modelling and DGT," vol. 54, pp. 89-96, 2008, doi: 10.1016/j.coldregions.2008.01.003.

[10] A. A. Setiawan, D. Budianta, Suheryanto, and D. P. Priadi, "Contents of Heavy Metal in Soil and Water at Stockpile Coal (Case Study Kertapati Palembang City Indonesian)," Pollut. Res., vol. 37, no. 2, pp. 301-306, 2018.

[11] M. N. Saviour, "Environmental Impact of Soil and Sand Mining: a Review," Int. J. Sci. Environ., vol. 1, no. 3, pp. 125-134, 2012.

[12] S. P. Singh, L. Q. Ma, and W. G. Harris, "Heavy metal interactions with phosphatic clay: sorption and desorption behavior," J. Environ. Qual., vol. 30, no. 6, pp. 1961-1968, 1991, doi: 10.2134/jeq2001.1961.

[13] B. Wei and L. Yang, "A review of heavy metal contaminations in urban soils, urban road dusts and agricultural soils from China," Microchem. J., vol. 94, no. 2, pp. 99-107, 2010, doi: 10.1016/j.microc.2009.09.014.

[14] B. Qin et al., "Nickel ion removal from wastewater using the microbial electrolysis cell," Bioresour. Technol., vol. 121, pp. 458461, 2012, doi: 10.1016/j.biortech.2012.06.068.

[15] D. G. Kim et al., "Agro-industrial wastewater treatment by electrolysis technology," Int. J. Electrochem. Sci., vol. 8, no. 7, pp. 9835-9850, 2013.

[16] I. F. Mena, S. Cotillas, E. Díaz, C. Sáez, Á. F. Mohedano, and M. A. Rodrigo, "Influence of the supporting electrolyte on the removal of ionic liquids by electrolysis with diamond anodes," Catal. Today, vol. 313, no. October, pp. 203-210, 2018, doi: 10.1016/j.cattod.2017.10.025.

[17] M. M. Islam, T. Okajima, S. Kojima, and T. Ohsaka, "Water electrolysis: An excellent approach for the removal of water from ionic liquids," Chem. Commun., no. 42, pp. 53305332, 2008, doi: 10.1039/b811174j.

[18] R. Rusdianasari, A. Meidinariasty, and I. Purnamasari, "Level Decreasing Kinetics Model of Heavy Metal Contents in The Coal Stockpile Wastewater with Electrocoagulation," Int. J. Adv. Sci. Eng. Inf. Technol., vol. 5, no. 6, pp. 387-391, 2015.

[19] M. V. A. Ramakrishna and S. Venugopal Rao, "Fabrication of ECM and study of its parameters in $\mathrm{NaCl}$ electrolyte," Mater. Today Proc., vol. 46, no. xxxx, pp. 934-939, 2021, doi: 10.1016/j.matpr.2021.01.181.

[20] P. A. Carneiro, C. S. Fugivara, R. F. P. Nogueira, N. Boralle, and M. V. B. Nivaldo, "A Comparative Study on Chemical and Electrochemical Degradation of Reactive Blue 4 Dye," Port. Electrochim. Acta, vol. 21, no. 1, pp. 49-67, 2003, doi: 10.4152/pea.200301049.

[21] S. Curteanu, C. G. Piuleac, K. Godini, and G. Azaryan, "Modeling of electrolysis process in wastewater treatment using different types of neural networks," Chem. Eng. J., vol. 172, no. 1, pp. 267-276, 2011, doi: 10.1016/j.cej.2011.05.104.

[22] A. Kapałka, G. Fóti, and C. Comninellis, "Kinetic modelling of the electrochemical mineralization of organic pollutants for wastewater treatment," J. Appl. Electrochem., vol. 38, no. 1, pp. 7-16, 2008, doi: 10.1007/s10800-007-9365-6.

[23] M. N. Priya and K. Palanivelu, "Removal of total dissolved solids with simultaneous recovery of acid and alkali using bipolar 
membrane electrodialysis-Application to RO reject of textile effluent," Indian J. Chem. Technol., vol. 13, no. 3, pp. 262-268, 2006.

[24] A. Shafaei, M. Rezayee, M. Arami, and M. Nikazar, "Removal of $\mathrm{Mn} 2+$ ions from synthetic wastewater by electrocoagulation process," Desalination, vol. 260, no. 1-3, pp. 23-28, 2010, doi: 10.1016/j.desal.2010.05.006.

[25] E. Jahed, M. H. H. Khodaparast, F. Lotfian, and A. Mousavi Khaneghah, "Performance Investigation of Electrochemical Treatment Process on Wastewater of Applicable Decolorization Resins in Sugar Factories," Sugar Tech, vol. 16, no. 3, pp. 311-318, 2014, doi: 10.1007/s12355-013-0250-9.

[26] H. Y. Shim et al., "Application of Electrocoagulation and Electrolysis on the Precipitation of Heavy Metals and Particulate Solids in Washwater from the Soil Washing," $J$. Agric. Chem. Environ., vol. 03, no. 04, pp. 130 138, 2014, doi: 10.4236/jacen.2014.34015. 